\title{
Оценка флюидонасыщенности Алтае-Саянской складчатой области по данным магнитотеллурических зондирований
}

Белявский В. В., Лозовский И. Н.

\begin{abstract}
Аннотация
Представлена модель глубинной электропроводности Алтае-Саянской складчатой области, составленная по результатам трехмерной инверсии инвариантных значений матрицы импеданса и интерактивного подбора трехмерных модельных кривых магнитотеллурического зондирования к экспериментальным. По полученным значениям удельного электрического сопротивления выполнена оценка флюидонасыщенности земной коры по формуле Шенкленда - Ваффа. Минерализация водного раствора солями $\mathrm{NaCl}$ принята равной 170 г/л, при котором флюидонасыщенность соответствует ее оценке по сейсмическим данным. Изучена электропроводность и насыщенность флюидом очаговых зон землетрясений, активизированных блоков региона и глубинных разломов. Основная часть гипоцентров землетрясений расположена над кровлей электропроводящих блоков земной коры и вблизи глубинных низкоомных разломов. Положение низкоомных аномалий электропроводности коррелирует с положением доменов, характеризующихся повышенным затуханием обменных волн землетрясений и пониженными скоростями продольных волн. Максимальным содержанием флюида (0.5 - 0.9 \%) характеризуются Тээлинский, Самагалтайский и Каа-Хемский очаги землетрясений, а минимальным (0.1 - 0.2 \%) Алтайский, Шапшальский, Шагонарский и Большепорошский очаги. Флюидонасыщенность глубинных разломов достигает 1.2 \%, причем минимальное содержание флюида свойственно разломам, относительно которых растягивающие напряжения, ориентированные ортогонально к их простиранию, характеризуются минимальными значениями. Это справедливо и для блоков коры, расположенных под впадинами. Высокое содержание флюида под Кызылской впадиной и ее обрамлением коррелирует с высоким дефицитом скорости продольных волн, наблюдаемым под ней.
\end{abstract}

\section{Ключевые слова:}

магнитотеллурические зондирования, глубинное строение, флюидонасыщенность земной коры, удельное электрическое сопротивление, очаговые зоны землетрясений 


\title{
ОЦЕНКА ФЛЮИДОНАСЫЩЕННОСТИ ЛИТОСФЕРЫ АЛТАЕ-САЯНСКОЙ СКЛАДЧАТОЙ ОБЛАСТИ ПО ДАННЫМ МАГНИТОТЕЛЛУРИЧЕСКИХ ЗОНДИРОВАНИЙ
}

\author{
В.В. Белявский, И.Н. Лозовский \\ Центр геоэлектромагнитных исследований - филиал \\ Института физики Земли им. О.Ю. Шмидта РАН (ЦГЭМИ ИФЗ РАН), \\ 108840, г. Москва, г. Троицк, а/я 30 \\ E-mail: victor.belyavsky@list.ru, i.n.lozovsky@yandex.ru
}

Аннотация. Представлена модель глубинной электропроводности Алтае-Саянской складчатой области, составленная по результатам трехмерной инверсии инвариантных значений матрицы импеданса и интерактивного подбора трехмерных модельных кривых магнитотеллурического зондирования к экспериментальным. По полученным значениям удельного электрического сопротивления выполнена оценка флюидонасыщенности земной коры по формуле Шенкленда - Ваффа. Минерализация водного раствора солями $\mathrm{NaCl}$ принята равной 170 г/л, при котором флюидонасыщенность соответствует ее оценке по сейсмическим данным. Изучена электропроводность и насыщенность флюидом очаговых зон землетрясений, активизированных блоков региона и глубинных разломов. Основная часть гипоцентров землетрясений расположена над кровлей электропроводящих блоков земной коры и вблизи глубинных низкоомных разломов. Положение низкоомных аномалий электропроводности коррелирует с положением доменов, характеризующихся повышенным затуханием обменных волн землетрясений и пониженными скоростями продольных волн. Максимальным содержанием флюида (0.5 - 0.9 \%) характеризуются Тээлинский, Самагалтайский и Каа-Хемский очаги землетрясений, а минимальным (0.1 $0.2 \%)$ - Алтайский, Шапшальский, Шагонарский и Большепорошский очаги. Флюидонасыщенность глубинных разломов достигает 1.2 \%, причем минимальное содержание флюида свойственно разломам, относительно которых растягивающие напряжения, ориентированные ортогонально к их простиранию, характеризуются минимальными значениями. Это справедливо и для блоков коры, расположенных под 
впадинами. Высокое содержание флюида под Кызылской впадиной и ее обрамлением коррелирует с высоким дефицитом скорости продольных волн, наблюдаемым под ней.

Ключевые слова: магнитотеллурические зондирования, глубинное строение, флюидонасыщенность земной коры, удельное электрическое сопротивление, очаговые зоны землетрясений.

\section{ВВЕДЕНИЕ}

Прогноз сейсмической опасности требует выявления особенностей глубинного строения очаговых зон землетрясений и сопредельных блоков литосферы, являющихся источниками избыточного давления и областями его перераспределения. Последнее обстоятельство определяется и содержанием флюида, который связан с процессами метаморфической дегидратации горных пород. Временной ход перераспределения напряжений в блоках земной коры может контролироваться механическим взаимодействием породы и коровой жидкости [Райс, 1982]. Сейсмическая активность чаще всего проявляется при сочленении структур с контрастными геоэлектрическими показателями, высокими горизонтальными градиентами сейсмических скоростей или с различным поглощением поперечных волн [Киссин, 2009; Каракин и др., 2003]. Содержание водного флюида в земной коре и верхней мантии можно оценить из распределения удельного электрического сопротивления (УЭС) блоков литосферы, получаемого в результате трехмерной интерпретации магнитотеллурических (MT) данных.

Алтае-Саянский регион характеризуется крайне высокой интенсивностью сейсмических сотрясений - до 8 - 9 баллов (рис. 1). С целью исследования его глубинного строения, сейсмотектонического районирования, а также выявления рудоперспективных зон выполнены тысячи километров профилей методами магнитотеллурического зондирования (МТ3) и обменных волн землетрясений (МОВ3), пересекающих основные очаговые зоны землетрясений.

Магнитотеллурические наблюдения, выполняемые по всему миру, подтвердили свою эффективность для разведки геотермических и геотермальных ресурсов, исследования вулканической деятельности, изучения строения зон субдукции, сдвига, глубинных разломов, зон графитизации, при морских исследованиях, при решении рудных и многих других задач. Характерной особенностью этих исследований является, в 
основном, трехмерный подход к интерпретации МТ данных и объяснение получаемых аномалий УЭС петрофизическими, минералогическими, гидрогеологическими и структурными особенностями строения изучаемых блоков литосферы. Опыты по трехмерной объединенной инверсии тензора импеданса и матрицы искажения [Avdeeva et al., 2015], проведенные на синтетических MT данных для различных типов искажений кривых МТЗ, показали, что данный подход улучшает оценки УЭС глубинных частей моделей по сравнению с 3D инверсией MT импеданса без предварительного снятия этих искажений. Учет влияния локальных неоднородностей на кривые МТЗ проводился и при трехмерной их интерпретации в Алтае-Саянской складчатой области, путем их осреднения в группах конформных кривых МТЗ, ориентированных по одному направлению [Белявский, 2014; Белявский, 2017].

Отличительной особенностью представленных в настоящей статье результатов, является проведение трехмерной инверсии и $3 \mathrm{D}$ моделирования, как всех компонент матриц импедансов, так и их инвариантных значений. Показано, что применение последних существенно упрощает процесс сравнения модельных и экспериментальных импедансов, снижает время вычислительных процессов и повышает достоверность построения геоэлектрических моделей [Белявский, 2020; Белявский, Лозовский, 2020; Белявский, 2017]. Достоверность геоэлектрических построений определялась близостью моделей, полученных методом 3D инверсии экспериментальных кривых MT3 (программа WSINV3DMT [Siripunvaraporn et al., 2005]) и методом подбора к ним 3D модельных инвариантных кривых МТЗ (программы [Druskin, Knizhnerman, 1994; Белявский, 2007]), а также совпадением экспериментальных кривых МТЗ и фаз импедансов (с учетом минимума погрешности подбора) с их модельными аналогами, полученными при 3D инверсии и 3D моделировании экспериментальных MT данных.

Исследования по оценке разрешающей способности 3D модельных кривых MT3 [Белявский и др., 2018; Белявский, 2014] показали, что полученные распределения УЭС должны быть близки к истинным значениям УЭС в проводящих блоках коры, если модельные блоки с высокой проводимостью отвечают их геометрическим параметрам. Для построенных геоэлектрических моделей очагов землетрясений, зон возможной рудной минерализации и сопредельных к ним территорий [Белявский, 2020; Белявский, Лозовский, 2020], выполнена оценка флюидонасыщенности проводящих блоков коры. 


\section{КРАТКАЯ ГЕОЛОГО-ГЕОФИЗИЧЕСКАЯ ХАРАКТЕРИСТИКА РАЙОНА ИССЛЕДОВАНИЯ И ОЧАГОВ ЗЕМЛЕТРЯСЕНИЙ}

Рассматриваемая часть Алтае-Саянской складчатой области размещается в пределах разновозрастных геоблоков: протерозойских (Западно-Сангиленский и ТомскоТерский), байкалид (Южно-Чуйский, Батеневский и Мрасский массивы), каледонид (Западные Саяны, Юго-Восточная Тува и Горный Алтай). В пределах этих геоблоков располагается ряд межгорных впадин и прогибов: на севере - Северо- и ЮжноМинусинская впадины, в центральной части региона - Хемчикский, Тувинский прогибы; Улуг-Хемская, Тувинская и Казылская впадины, а на юге - Убсунурская, Курайская и Чуйская впадины, заполненные осадочно-вулканогенными образованиями нижнегосреднего девона, молассой среднего-верхнего девона и угленосными отложениями карбона - юры (рис. 1). В пределах региона выделены устойчивые массивы: Бийско-Барнаульский и Хакасский, включающий в себя Батеневский и Мрасский выступы фундамента [Матросов, Шапошников, 1988].

Минусинская котловина разделяется байкалидами Мрасского и Батеневского выступов на Северо- и Южно-Минусинскую впадины. Площадь исследований пересекают глубинные разломы с ориентацией: северо-восточной (Сардино-Сорский, СаяноБатеневский, Саяно-Минусинский), северной (Мартайгинско-Патынский) и западной (Батеневский). Эти разломы характеризуются унаследованным режимом развития и играют ведущую роль в рудоформировании, поскольку обрамлены трещинами различной направленности, что способствовало протеканию гидротермального процесса и рудоотложению. Кристаллический фундамент в Минусинских впадинах залегает на глубине 8 - 10 км. Минерализация вод в их пределах превышает 100 г/кг [Матросов, Шапошников, 1988], а концентрация гелия - 0.3 - 1.6 \%, что свидетельствует о глубинном заложении разломов, достигающих верхней мантии.

Горно-Алтайский участок исследований на западе ограничен Сарасинским и Восточно-Кузбасским глубинными разломами, на востоке Каа-Хемкским и ВосточноСаянским разломами, на севере Северо-Минусинской, а на юге Убсунурской впадинами (рис. 1). Система глубинных разломов субширотного, северо-западного и северовосточного простирания разделяет структурно-формационные зоны (СФ3) зеленосланцевых выступов байкалид, каледонид орогенной стадии развития, раннеорогенных вулканогенно-молассоидных и позднекаледонских миогеосинклинальных образований посторогенной активизации. По северо-западным фрагментам разломов 
формируются сдвиги и взбросо-сдвиги, а по субширотным - надвиги. Сарасинский, Шапшальский, Восточно-Шапшальский, Башеланский, Курайский, Борусский, Хемчикско-Куртушибинский, Уюкский, Южно-Тонноульский и Шуйский разломы характеризуются унаследованным режимом развития и проникновением в литосферу. Они играют ведущую роль в распределении сейсмичности, поскольку по ним происходит разгрузка тектонических напряжений, а по Каа-Хемскому, Азасскому, Агардагскому, Восточно-Таннуольскому разломам и перемещение блоков коры. К местам пересечения разломов приурочены впадины, погружающиеся со скоростью до 0.7 мм/год, а обрамляющие их блоки поднимаются со скоростью до 1.5 мм/год [Матросов, Шапошников, 1988].

Активизация региона началась в мезозое и с перерывами продолжается до настоящего времени. Нынешняя стадия активизации проявляется в усилении вертикальных движений в области поднятий и прогибов и сжатии в северо-северозападном, в основном, положительных структур Горного Алтая, и северо-северовосточном направлениях - структур Восточных Саян, включая обрамление Кызылской впадины [Матросов, Шапошников, 1988; Буслов и др., 2013]. Южнее региона выделяется низкоскоростной мантийный блок с пониженной скоростью продольных волн (7.7 - 7.8 км/с). По нему кора сползает в северном направлении, и в неё внедрялись расплавленные мантийные диапиры, которые сформировали структуры в её верхней части.

Наблюдается зависимость напряженного состояния земной коры от положения глубинных коровых и мантийных блоков [Кузнецова, 1997] и от механизмов эрозии и денудации, которые приводят к горизонтальным сжатиям в пределах поднятий и девиаторным растяжениям под межгорными впадинами [Ребецкий и др., 2013].

К границам впадин и окружающих их поднятиям приурочено 60 \% сейсмических событий. Регион характеризуется сейсмичностью с магнитудой $M>6$. В его пределах выделяются Алтайская, Шапшальская, Тээлинская, Шагонарская, Каа-Хемская, Большепорожская и Самагалтайская очаговые зоны землетрясений. Параметры зон, в которых произошли землетрясения с магнитудой свыше 4 (магнитуды и глубины до главных событий $M_{h y}, \mathrm{H}_{\mathrm{hy}}$, их афтершоков $M_{\mathrm{af}}, \mathrm{H}_{\mathrm{af}}$, размеры эпицентрального поля, его расположение, суммарные амплитуды перемещений блоков коры), приведены в Табл. 1 с учетом работ [Монгуш, 2015; Еманов и др., 2014; Еманов и др., 2017; Еманов, Лескова, 2005; Лескова, Еманов, 2013; Лескова, 2014]. 


\section{МЕТОДИКА ПОСТРОЕНИЯ ТРЕХМЕРНЫХ ГЕОЭЛЕКТРИЧЕСКИХ МОДЕЛЕЙ}

Магнитотеллурические зондирования региона исследований. Вдоль сети региональных профилей в рассматриваемой части Алтае-Саянского региона выполнены магнитотеллурические зондирования в диапазоне периодов от 0.003 до 10000 с применением станций SGS-E («СибГеоСейс», г. Новосибирск). Наблюдения проведены в пределах - Кузнецкого Алатау (северная площадь), Западных Саян и Тувы (центральная площадь), Горного Алтая (южная площадь) и серии соединяющих их профилей (рис. 1). Шаг между зондированиями составил 1.5 - 3 км.

Первичная обработка МТ данных проводилась в ГФУГП «Иркутскгеофизика» с применением программного обеспечения SGS-Processing (стандартные алгоритмы узкополосной фильтрации и решения переопределенной системы уравнений). Относительная среднеарифметическая погрешность оценивания модулей главных компонент тензора импеданса $\left|\mathrm{Z}_{\mathrm{xy}}\right|$ и $\left|\mathrm{Z}_{\mathrm{yx}}\right|$ составила около 5 \%, а среднеарифметическая погрешность оценивания их фаз $-2^{\circ}-3^{\circ}$.

Углубленная обработка МТ данных с построением инвариантных кривых магнитотеллурического зондирования, анализом матриц импедансов, одномерной инверсией и взаимными преобразованиями кривых МТЗ в кривые фазового тензора или другие типы инвариантных значений матриц импедансов выполнялась по методикам, описанным в работе [Белявский, 2017]. Оценена преимущественная ориентация максимальных $\left|\mathrm{Z}_{\operatorname{maxH}}\left(\Theta_{\text {maxн }}\right)\right|$ и минимальных $\left|\mathrm{Z}_{\min }\left(\Theta_{\min H}\right)\right|$ инвариантных кривых МТЗ [Counil et al., 1986]. Поскольку большинство кривых $\left|Z_{x y}\right|$ и $\left|Z_{\text {yх }}\right|$ строились вдоль измерительных линий, ориентированных по осям эллипса поляризации электрического поля, то в рассматриваемые максимальные инвариантные значения тензора импеданса | $\left.\mathrm{Z}_{\operatorname{maxH}}\left(\Theta_{\operatorname{maxH}}\right)\left|=\frac{\square}{\mid}\right| \mathrm{Zxx}\left(\theta_{\max H}\right)\right|^{2}+\left|\mathrm{Z} \mathrm{yx}\left(\theta_{\max H}\right)\right|^{2} \square^{1 / 2}$ основной вклад дает погрешность определения импедансов $\left|\mathrm{Z}_{\mathrm{yx}}\left(\Theta_{\text {mахн }}\right)\right|$, которые ориентированы достаточно близко к направлениям измерительных линий, и абсолютная погрешность которых обычно значительно превышает погрешности дополнительных импедансов $\left|Z_{x x}\left(\Theta_{\text {maxн }}\right)\right|$. Аналогичная ситуация имеет место и для минимальных инвариантных значений | $\mathrm{Z}_{\operatorname{minH}}\left(\Theta_{\min H}\right) \mid$.

Интерпретация МТ данных выполнена с применением двух подходов к решению обратной задачи: трехмерной инверсии МТ данных в пределах центральной и южной 
площадей (рис. 1) и интерактивным подбором трехмерных модельных кривых МТЗ к экспериментальным во всем исследуемом регионе.

Метод интерактивного подбора трехмерных кривых МТЗ. Численное трехмерное моделирование МТ полей выполнялось конечно-разностным методом с использованием схемы спектрального приближения через собственные пары матриц системы уравнений, полученных в процессе Ланцоша, с применением программы Maxwellf [Druskin, Knizhnerman, 1994]. При решении обратной МТ задачи методом подбора последовательно решались следующие задачи:

- анализ матриц экспериментальных импедансов $\left[\mathrm{Z}_{\mathrm{ob}}\right]$ с определением их размерности и направления главных осей [Бердичевский и др., 1997];

- вычисление инвариантных значений $\mathrm{Z}_{\text {maxH }}^{\mathrm{ob}}$ и $\mathrm{Z}_{\text {ob }}^{\mathrm{minH}}$ матрицы импеданса $\left[\mathrm{Z}_{\mathrm{ob}}\right]$ [Counil et al., 1986];

- учет влияния локальных неоднородностей верхней части разреза на кривые МТЗ путем их нормализации;

- проведение 1D-2D инверсий нормализованных импедансов $\mathrm{Z}_{\text {maxHN }}^{\text {и }} \mathrm{Z}_{\text {minHN }}^{\text {ob }}$ [Белявский, 2017; Варенцов, 2002];

- составление синтезированных стартовых 3D моделей из 1D - 2D геоэлектрических моделей;

- построение 3D моделей методом подбора 3D модельных кривых $\rho_{m}^{\operatorname{maxH}}, \rho_{m}^{\operatorname{minH}} \mathrm{K}$ наблюденным средним нормализованным кривым $\rho_{o b}^{\stackrel{v}{\max H N}}, \rho_{o b}^{\operatorname{vin} H N}$.

Анализ матриц экспериментальных импедансов показал, что в пределах большей части региона исследований, в диапазоне периодов, отражающем электропроводность нижнего структурного этажа (ниже уровня подошвы максимальной мощности осадочного чехла впадин), параметры асимметрии указывают на трехмерную размерность среды. Определение ориентации и значений инвариантных импедансов и нормализация кривых МТЗ для данного региона выполнялись по методике, изложенной в работе [Белявский, 2017].

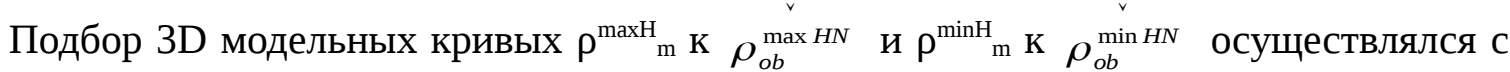
учетом геоэлектрической модели верхнего структурного этажа, полученной в результате 1D- и 2D-инверсии MT данных. Вычислялась относительная среднеарифметическая $\stackrel{v}{\delta}$ 
Zmaxн погрешность подбора $\left|Z_{\mathrm{m}}^{\mathrm{maxH}}(\mathrm{T})\right|$ к среднему значению в группе $\left|\check{Z}^{\operatorname{maxH}}{ }_{\mathrm{ob}}(\mathrm{T})\right|=(1 \backslash \mathrm{N})$ $\sum_{i=1}^{N}\left|Z_{i}^{\max H}{ }_{o b}\right|(\mathrm{T})$, где $\mathrm{N}$ - количество нормализованных экспериментальных импедансов. Аналогично определялась погрешность $\check{\delta}^{\mathrm{ZminH}}$ для импедансов $\left|Z^{\mathrm{minH}}{ }_{\mathrm{m}}(\mathrm{T})\right|$ и $\left|\check{Z}^{\mathrm{minH}}{ }_{\mathrm{ob}}(\mathrm{T})\right|$. Относительные суммарные среднеарифметические погрешности кривых МТ3 $\overbrace{\delta}^{\text {pmaxн } и ~}$ pminH составили для Кузнецкого Алатау - 12 и 20 \%, Горного Алтая - 35 и 50 \%, Тувы и Западных Саян - 26 и 40 \%. При рассмотрении кривых в усеченном диапазоне периодов относительные погрешности значительно уменьшаются.

3D-инверсия MT данных. В пределах центральной и южной площадей региона исследований выполнена трехмерная инверсия магнитотеллурических данных с использованием программного обеспечения WSINV3DMT [Siripunvaraporn et al., 2005]. Прямая задача решалась методом конечных разностей. При решении обратной задачи минимизация Тихоновского функционала невязки между наблюденными и модельными данными выполнялась с учетом получения сглаженных изменений УЭС по латерали и вертикали. В качестве штрафной функции рассматривался член, учитывающий параметры стартовой модели.

Для уточнения методики проведения инверсии и оценки ее разрешающей способности предварительно была выполнена 3D-инверсия модельных (тестовых) данных, полученных в результате решения прямой задачи от геоэлектрических моделей, принятых по данным метода интерактивного подбора. Для тестовых моделей Горного Алтая, Тувы и Западных Саян, при относительных среднеарифметических погрешностях трехмерной инверсии $\delta^{\text {pxy }}{ }_{\text {in }}$ и $\delta^{\text {pyx }}$ in достигающих 15 - $25 \%$, параметры восстановленных блоков в верхней части моделей были близки к их тестовым значениям, но в нижних частях моделей расхождение между ними было более значительным [Белявский, 2020; Белявский, Лозовский, 2020].

Максимальные значения $\delta^{p x y}$ in $и \delta^{\text {pyx }}$ in не всегда приходятся на участки моделей, где получаемые при трехмерной инверсии $\rho^{\text {in }}\left(\mathrm{H}^{\text {in }}\right)$ значительно отклонены от тестовых значений $\rho^{\mathrm{m}}\left(\mathrm{H}_{\mathrm{m}}\right)$, а минимальные $\delta^{\rho \mathrm{xy}}{ }_{\text {in }}$ и $\delta^{\text {pyx }}{ }_{\text {in }}$ появляются и там, где выделяются псевдопроводники, вызванные влиянием заданных на смежных профилях низкоомных модельных блоков. Исследования на тестовых моделях показали, что по программе WSINV3DMT инвертировать импедансы $\mathrm{Z}^{\mathrm{maxH}}{ }_{\mathrm{m}}$ и $\mathrm{Z}^{\mathrm{minH}}{ }_{\mathrm{m}}$ предпочтительнее, чем все компоненты матрицы $\left[\mathrm{Z}_{\mathrm{m}}\right]$. 
B качестве входных экспериментальных MT данных при их 3D-инверсии рассматривались как четыре комплексные компоненты матрицы импеданса $\left[\mathrm{Z}_{\mathrm{ob}}\right]$, так и ее максимальные и минимальные значения $\mathrm{Z}^{\operatorname{maxH}}{ }_{\text {ob}}, \mathrm{Z}^{\mathrm{minH}}{ }_{\text {ob. }}$. Однако результирующие геоэлектрические модели принимались с учетом проведенных исследований разрешающей способности импедансов $\mathrm{Z}_{\mathrm{maxH}}^{\mathrm{m}}, \mathrm{Z}_{\mathrm{m}}^{\mathrm{minH}}$ на тестовых 3D моделях и использования при 3Dинверсии экспериментальных данных серий стартовых моделей, которые позволили подобрать параметры блоков, для которых достигается минимальное расхождение между импедансами $\check{Z}_{\text {obaxH }}{ }_{\text {ob }}{ }_{\text {minH }}{ }_{\text {ob }}$ и, получаемыми при 3D инверсии, значениями $\mathrm{Z}^{\mathrm{xy}}{ }_{\mathrm{in}}, \mathrm{Z}^{\mathrm{yx}}{ }_{\text {in }}$

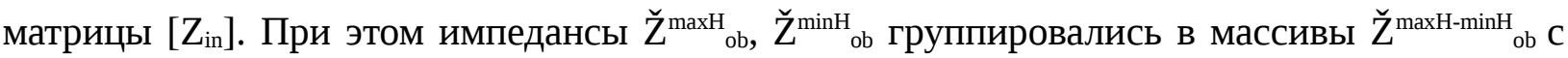
учетом их ориентации, близкой к направлениям осей $\mathrm{X}$ или $\mathrm{Y}$ в точках инверсии (т.и.) на сетке дискретизации 3D модели. Эти точки инверсии отвечают положению точек наблюдения (т.н.) на рис. 1, а сами сетки дискретизации представлены в работах [Белявский, 2020; Белявский, Лозовский, 2020].

Перед решением трехмерной обратной задачи МТЗ оценивалась разрешающая способность различных типов инвариантных кривых МТЗ к определению параметров проводящих структур в моделях литосферы и при построении стартовых геоэлектрических моделей с помощью процедуры 1D инверсии [Белявский, 2014, т. 1]. Описанная выше методика позволяет оценивать УЭС разломов, проводящих блоков в средних и нижних частях коры и их глубину расположения для большинства тестовых моделей. При этом 3D инверсия импедансов $\mathrm{Z}_{\text {obaxH }} \mathrm{Z}_{\text {ob }}^{\mathrm{minH}}$, упрощает процедуры минимизации функционала невязки и уменьшает число сравниваемых компонент матрицы импеданса при выборе результирующей $3 \mathrm{D}$ модели - с восьми параметров в $\left[\mathrm{Z}_{\mathrm{ob}}\right]$ до четырех, сокращая машинное время, затраченное на решение обратной задачи.

\section{ОЦЕНКА СОДЕРЖАНИЯ ДОЛЕЙ ВОДНОГО ФЛЮИДА}

Методика расчета содержания флюида. Наиболее вероятной причиной высокой проводимости коры на глубинах 20 - 30 км являются процессы дегидратации пород, возникающие при температурах $600^{\circ}-800^{\circ} \mathrm{C}$, достаточных для преобразования пород амфиболитовой фации метаморфизма [Браун, Массет, 1984]. Объем образовавшейся химически не связанной воды может достигать 1 - 2 \% от объема коры, а содержание связанной и свободной долей - до 4 \% [Каракин и др., 2003]. Концентрирование водной фракции флюида в коре активизированных регионов наступает при протекании процессов дилатансионного расширения [Файф и др., 1981]. Например, в момент землетрясения в его 
очаге и вблизи него образуются трещины, концентрирующие флюид, а слабая миграция флюида через верхние слои земной коры позволяет ему сохраниться в средней коре.

Оценка удельной электрической проводимости двухфазных пород коры (скелета и флюида) выполнялась по формуле Шенкленда-Ваффа $\sigma=\left[\sigma_{\mathrm{f}}+\left(\sigma_{\mathrm{s}}-\sigma_{\mathrm{f}}\right) \cdot\left(1-2 / 3 \boldsymbol{\phi}_{\mathrm{p}}\right)\right] /\left[1+\left(\boldsymbol{\phi}_{\mathrm{p}} / 3\right)\right.$ $\left.\left(\sigma_{s} / \sigma_{f}-1\right)\right]$, где $\sigma_{f}$ и $\sigma_{s}-$ удельные проводимости флюида и скелета горной породы [Shankland, Waff, 1977], а фр содержание флюида (в объемных долях). Эта формула подразумевает наличие связанных в проводящие цепи все части флюида. В упомянутой статье показано, почему удобнее пользоваться ф. Шенкленда-Ваффа по сравнению с формулой Аррениуса, в которой необходимо знать ряд дополнительных параметров о составе матрицы горной породы и флюида, заполняющего её поры. При содержании флюида фр менее 15 \%, его полной связанности в блоках коры и выполнении условия $\sigma_{\mathrm{f}}>>$ $\sigma_{\mathrm{s}}$, формула Шенкленда-Ваффа существенно упрощается и принимает вид $\sigma=2 \sigma_{\mathrm{f}} \cdot \mathbf{\phi}_{\mathrm{\rho}} / 3$. Это выражение отвечает модифицированному закону Арчи [Archie, 1950], который подтвержден численными расчетами проводимости для блоков, содержащих кубические или шаровые высокоомные включения, вдоль границ, в которых распределена жидкость. Уменьшение содержания связанных в токовые нити долей флюида $\left(\boldsymbol{\phi}_{\mathbf{p}}\right)$ в два раза, при той же их концентрации, ведёт к увеличению УЭС блоков горных пород в 10 раз [Ваньян, 1997].

Электропроводность флюида, минерализованного солями NaCl. По измерениям в скважинах минерализация водного раствора $(\boldsymbol{C})$ солями $\mathrm{NaCl}-\mathrm{KCl}$ в регионе исследований изменяется от 10 до 300 г/л [Моисеенко, Смыслов, 1986]. При минерализации флюида солями $\mathrm{NaCl} 10,50,170$ г/л и температуре $18^{\circ}$ его УЭС ( $\left.\rho_{\mathrm{f}}\right)$ составляет $\rho_{\mathrm{f}}^{10}=0.6, \rho_{\mathrm{f}}^{50}=0.17$ и $\rho_{\mathrm{f}}^{170}=0.07$ Ом·м [Физические свойства..., 1984]. Изменение $\rho_{\phi}$ с увеличением давления и температуры $(T)$, согласно работе [Ваньян, 1997], представлено в Табл. 2, строки 1 - 3.

Блок коры с УЭС 10 Ом•м, расположенный на глубинах 25 - 35 км (при $T=525$ 825), может быть насыщен флюидом, минерализованным солями $\mathrm{NaCl}$, при полной связанности всех его долей, участвующих в переносе тока с: $\boldsymbol{\phi}_{\rho}{ }^{10}=0.8-1.0 \%(\boldsymbol{C}=10$ г/л), $\boldsymbol{\phi}_{\rho}{ }^{50}=0.2-0.25 \%\left(\boldsymbol{C}=50\right.$ г/л) и $\boldsymbol{\phi}_{\rho}{ }^{170}=0.08-0.1 \%(\boldsymbol{C}=170$ г/л). При частично связанных долях флюида, с учетом адсорбции части ионов $\mathrm{Na}^{+}, \mathrm{Cl}^{-}$на стенках капилляров и их содержании в карманах обводненных кварцитах и с $\boldsymbol{C}=170$ г/л (четвертая строка табл. 2) $\boldsymbol{\phi}_{p}{ }^{170}$ возрастает до $0.7 \%$ [Shimojuku et al., 2014].

На глубинах 10 - 15 км флюид с хлоридной минерализацией в $\boldsymbol{C}=40$ г/л имеет $\rho_{\mathrm{f}}=$ $0.02-0.04$ Ом·м [Ваньян, Хайдман, 1996], что близко к значениям $\rho_{\mathrm{f}}^{50}$ в табл. 2. Его 
содержание при дегидратации флюида оценивается в $\boldsymbol{\phi}_{p}=1.5 \%$, но в связанном состоянии долей водного флюида может находиться лишь их десятая часть, то есть 0.15 \% [Ваньян, 1997], которые и определяют его УЭС. Эти значения также близки к расчетным значениям $\rho_{\mathrm{f}}^{170}$ в четвертой и третьей строках табл. 2.

Содержание всех долей водного флюида $\boldsymbol{\phi}_{\mathbf{v}}$ в рассматриваемом блоке коры оценивалось по дефициту скорости продольных волн $\mathrm{V}_{\mathrm{p}}$, согласно уравнению среднего времени $1 / \mathrm{V}_{\mathrm{p}}=\boldsymbol{\phi}_{\mathrm{v}} / \mathrm{V}_{\mathrm{f}}+\left(1-\boldsymbol{\phi}_{\mathrm{v}}\right) / \mathrm{V}_{\mathrm{po}}$, где $\mathrm{V}_{\text {ро }}-$ скорость в скелете горной породы, a $\mathrm{V}_{\mathrm{f}}=1.7$ м/с - скорость во флюиде [Wyllie et al., 1956]. Более строгая оценка содержания ф্v, проведенная с учетом коэффициентов Пуассона, плотностей твердой и жидкой фаз [Петкевич, Вербицкий, 1965] показала, что при фы менее 2 \% различие между результатами двух подходов к расчету не превышает 5 - 10 \% [Белявский, 2017]. По данным метода обменных волн землетрясений погрешность определения $\mathrm{V}_{\text {p }}$ достигает 0.05 км/с, что дает нижний порог оценки фм в $0.2-0.22 \%$.

В блоке с $\rho=10$ Ом·м, при минерализации флюида 10 или 50 г/л, с учетом того, что не более половины долей флюида может находиться в связанном состоянии, содержание всех его долей должно достигать $10 \%$ для $\boldsymbol{\phi}^{\mathbf{1 0}}$ [Ваньян, 1997], что не отвечает сейсмическим оценкам $\boldsymbol{\phi}_{\mathbf{v}}$ в исследуемом регионе. Для $\boldsymbol{C}=50$ г/л содержание флюида $\boldsymbol{\phi}^{50}=$ 2.0 - 2.5 \%, что, в основном, также выше значений ф [Белявский, Ракитов, 2012]. В блоках с $\rho=10$ Ом·м, расположенных на глубинах $30-40$ км, при минерализации $\boldsymbol{C}=170$ г/л содержание всех долей должно достигать $\boldsymbol{\phi}^{\mathbf{1 7 0}}=0.7 \%$ [Shimojuku et al., 2014], если учитывается только часть ионов $\mathrm{Na}^{+}, \mathrm{Cl}^{-}$, которая переносит ток (табл. 2, четвертая строка). Оценка содержания флюида на более малых температурах и давлениях связана с экстраполяцией значения $\rho_{\mathrm{f}}=0.05$ Ом`м, определенного на образцах кварцита для глубины 35 км при $T=525-825^{\circ} \mathrm{C}$ [Shimojuku et al., 2014] согласно изменениям значений $\rho_{\mathrm{f}}^{170}$ в третьей строке табл. 2.

Надежность определяемых значений фр определяется не только достоверностью распределений $\rho^{\text {in }}\left(X^{\text {in }}, Y^{\text {in }}, Z^{\text {in }}\right)$, но и изменением с глубиной пористости, степенью связанности водных капель в проводящие цепи, отклонением природной минерализации флюида от принятой при оценке $\rho^{\mathrm{f}}$, которая задавалась с учетом полученных по сейсмическим данным значений ф.

\section{ГЛУБИННЫЕ ГЕОЭЛЕКТРИЧЕСКИЕ МОДЕЛИ АЛТАЕ-САЯНСКОГО РЕГИОНА}


В результате решения обратной задачи методами интерактивного подбора трехмерных модельных кривых МТЗ к экспериментальным кривым (для всего региона исследований) и 3D-инверсии (в пределах площадей Горный Алтай, Западные Саяны и Тува) построена глубинная геоэлектрическая модель Алтае-Саянской складчатой области. Карты удельного электрического сопротивления $\rho^{\text {in }}\left(Z^{\text {in }}\right)$ на глубинах $Z^{\text {in }}=10,20$ и 30 км представлены на рис. 2. Положение точек инверсии (т.и.) на рис. 2 и рис. 3, в которых инвертировались импедансы Ž ${ }_{\text {maxH }}{ }_{\text {ob }} \check{Z}^{\mathrm{minH}}$ ob отвечает группам квазиконформных экспериментальных кривых МТЗ в т.н., представленных на рис. 1.

Кузнецкий Алатау. Глубинные разломы - Сардино-Сорский, Саяно-Батеневский, Саяно-Минусинский и Мартайгинско-Патынский - выделяются на глубинах от 1 до 20 км блоками с УЭС от 10 до 400 Ом·м [Белявский, Гойдина, 2012]. Их положение коррелирует с областями латерального понижения скоростей $\mathrm{V}_{\mathrm{p}}$ по данным методов MOB3 - ГСЗ. Под профилем I блок с УЭС 50 - 70 Ом'м на глубине 30 км прилегает к областям с температурой $900^{\circ}$ C [Матросов, Шапошников, 1988] и зонам пониженных значений скоростей поперечных и продольных волн. Металлогенические зоны Батеневского массива (в основном, приразломные) выделяются на геоэлектрической модели значениями УЭС от 100 до 300 Ом·м.

Западные Саяны и Тува. На сечениях (рис. 2) и разрезах (рис. 3) [Белявский, Лозовский, 2020] геоэлектрической модели, на глубинах более 10 - 15 км под гипоцентрами землетрясений $\rho^{\text {in }}$ коры снижается под т.н.: 10 - 12, профиль Ж-Ж (КааХемский очаг) до 10 Ом·м; 6, профиль В-В (Большепорошский очаг) до 70 - 80 Ом•м; 1 - 2, профиль Б-Б (Шапшальский очаг) до 30 - 50 Ом·м; 2 - 4, профиль Г-Г и 7, профиль А-А (Тээлинский очаг) до 6 - 10 Ом`м; 11 - 12, 14 - 15 (Шагонарский очаг) и 20 - 22, 25 - 29 (Кызылская впадина), профиль Г-Г до 10 - 100 Ом•м; 19 - 20, профиль Б-Б (Самагалтайский очаг) до 20 Ом·м.

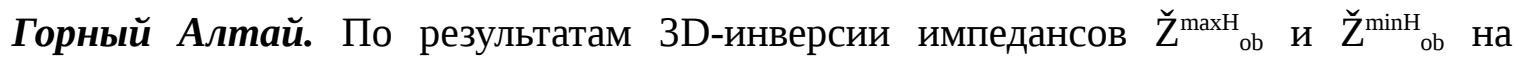
глубинах от 10 до 24 км под Чуйским и Шапшальским эпицентральными полями, вблизи разломов (Центрально-Чуйский, Курайский, РС и Шапшальский) под профилями наблюдений выделены блоки с $\rho^{\text {in }}=100$ Ом·м (Шапшальский очаг) и 60 - 80 Ом•м (Чуйский очаг). Под Шапшальским эпицентральным полем минимум УЭС смещен к югу от линии профиля 3-3 (от т.н. 17 - 18) к эпицентру Урэг-Нурского землетрясения. Глубже 40 км под этими очаговыми зонами УЭС возрастает. Блоки пониженных $\rho^{\text {in }}$ коррелируют с 
положением зон повышенного поглощения обменных волн землетрясений [Белявский, Ракитов, 2012].

Гипоцентры Алтайского землетрясения и его афтершоков концентрируются на глубинах 4 - 25 км (т.н. 14 - 15, профиль И-И), вблизи Центрально-Чуйского и РС разломов с $\rho^{\text {in }} \approx 100-200$ Ом`м, ограничивающих Чаган-Узунский выступ. Под профилем 3-3 аномалии с $\rho^{\text {in }}=10$ - 200 Ом·м отражают положение разломов северного и северозападного простирания [Белявский, 2020].

Под чехлом Западно-Сибирской плиты (западнее Ануйско-Чуйской СФЗ) на глубине 30 км выделен слой с УЭС 20 - 30 Ом•м (Каримов, [Геоэлектрическая модель..., 1998]), а восточнее - в Байкальской рифтовой зоне на глубинах 15 - 17 км - блок с УЭС 15 - 20 Ом·м (Бердичевский и др., [Геоэлектрическая модель..., 1998]). Местоположение последнего отвечает кровле волновода с дефицитом скорости $\Delta \mathrm{V}_{\mathrm{p}}=0.2-0.3 \mathrm{~km} / \mathrm{c}$ при средней коровой скорости $\mathrm{V}_{\mathrm{p}}=6.4$ - 6.5 км/с [Ваньян, Шиловский, 1983]. Если объяснить дефицит скорости водным флюидом, то его содержание оценивается в $\boldsymbol{\phi}_{\mathbf{v}}=1.0-1.6 \%$, что близко к оценке $\boldsymbol{\phi}_{\mathbf{p}}=0.6-0.9$ \% при минерализации флюида с $\mathbf{C}=170$ г/л.

\section{ФЛЮИДЫ И ТЕКТОНИКА АЛТАЕ-САЯНСКОГО РЕГИОНА}

По результатам 3D-инверсии кривых MT3 содержание флюида $\boldsymbol{\phi}_{\text {in }}{ }^{170}$ рассчитывалось для ядер низкоомных аномалий и зон с максимальным градиентом уменьшения $\rho^{\text {in }}\left(Z^{\text {in }}\right)$ с глубиной, а по результатам метода интерактивного подбора модельных кривых к экспериментальным содержание флюида $\mathbf{\phi}_{\mathbf{m}}{ }^{170}$ оценивалось для блоков с наиболее низкими значениями УЭС. Карта распределения флюида на глубинах более 5 км (при $\boldsymbol{C}=170$ г/л) представлена на рис. 4.

Дефицит скорости продольных волн и флюид. Под Кызылской впадиной по данным МОВ3 - ГСЗ выделены [Булин, Егоркин, 2000] домены с дефицитом скорости продольных волн на глубинах: $\mathrm{H}_{\mathrm{v}}=10 \mathrm{kм} \mathrm{с} \Delta \mathrm{V}_{\mathrm{p}}=0.15 \mathrm{kм} / \mathrm{c} \mathrm{под} \mathrm{блоком} \mathrm{с} \mathrm{V}_{\mathrm{p}}=6.15-6.20$ км/с ( $\left.\boldsymbol{\phi}_{\mathbf{v}} \approx 0.75 \%\right)$ и на $\mathrm{H}_{\mathrm{v}}=35$ км с $\Delta \mathrm{V}_{\mathrm{p}}=0.3 \mathrm{kM} / \mathrm{c}$ под блоком с $\mathrm{V}_{\mathrm{p}}=7.05 \mathrm{KM} / \mathrm{c}\left(\boldsymbol{\phi}_{\mathbf{v}} \approx 1.3 \%\right)$ [Белявский, 2017]. Им отвечает содержание флюида фin $^{170}=0.15$ \% в т.н. 12 профиля Д-Д и $\boldsymbol{\phi}_{\mathrm{in}}{ }^{170}=0.7-0.9$ \% в т.н. 26 - 27 профиля $\boldsymbol{\Gamma - \Gamma ~ ( р и с . ~ 2 , ~ 3 ) . ~}$

Под северной частью Алтайского эпицентрального поля на глубинах 10 - 20 км оценки $\boldsymbol{\phi}_{\rho}^{170}$ составляют 10 - $80 \%$ от $\boldsymbol{\phi}_{\mathrm{v}}$ [Белявский, 2017]. Юго-западнее Чуйского землетрясения (17.09.2003) на глубине 10 - 20 км, с учетом данных [Лисейкин, Соловьев, 
2005], $\boldsymbol{\phi}_{\mathrm{v}} \approx 0.25$ - $0.5 \%$, а $\boldsymbol{\phi}_{\text {in }}{ }^{170}=0.05$ - $0.2 \%$. Южнее в т.н. 9 - 11 профиля 3-3, на глубинах $\mathrm{H}_{\text {in }}=10$ 30 и 40 - 50 км различие между $\boldsymbol{\phi}_{\mathrm{v}}$ и $\boldsymbol{\phi}_{\text {in }}{ }^{170}$ не превьшает 10 - 40 \%, а в т.н. 3 - 6 профиля 3-3 на глубинах 10 - 15 км и 40 - 45 км расхождение значений возрастает до 50 - 80 \%. Под Шапшальским (т.н. 1 - 2 профиля Б-Б) и Тээлинским очагами (т.н. 6 - 9, профиля А-А) значения $\boldsymbol{\phi}_{\mathrm{v}} \approx \boldsymbol{\phi}_{\mathrm{in}}{ }^{170}$.

Сопоставления оценок содержания флюида по УЭС и скоростям распространения волн показывают, что доля $\boldsymbol{\phi}_{\text {in }}{ }^{170}$, рассчитанная при частичной адсорбции ионов $\mathrm{Na}^{+}$и $\mathrm{Cl}^{-}$, достигает значений 40 - 100 \% от $\boldsymbol{\phi}_{\mathbf{v}}$, что подтверждает правильность выбора для расчетов минерализации флюида в 170 г/л. Расчеты, проведенные для $\boldsymbol{\phi}_{\text {in }}{ }^{50}$ (при всех связанных долях флюида) противоречат положению $\boldsymbol{\phi}_{\mathbf{v}}>>\boldsymbol{\phi}_{\text {in }}{ }^{50}$. Некоторое различие между значениями $\boldsymbol{\phi}_{\mathbf{v}}$ и $\boldsymbol{\phi}_{\mathrm{in}}{ }^{170}$ может быть связано с более низкой минерализацией флюида в коре Алтае-Саянского региона или с более высокой адсорбцией ионов $\mathrm{Na}^{+}$и $\mathrm{Cl}^{-}$, чем получено при лабораторных исследованиях [Shimojuku et al., 2014]. Не исключено предположение и о повышенной гранитизации коры, например, под Батеневским массивом (профиль II), которое также ведет в дефициту скорости продольных волн, где на глубинах от 20 до 40 км под точками МТЗ 675 - 700, 726 - 720 ф $=0.4$ - $0.5 \%$ при $\boldsymbol{\phi}_{\text {in }}{ }^{170}=0.07$ - $0.15 \%$ [Белявский, 2017].

Флюид в очаговых зонах землетрясений и глубинных разломах. Из распределения значений 中in $^{170}$ следует, что повышенным содержанием флюида характеризуются блоки, расположенные на глубинах 15 - 25 км (рис. 4, 5) под гипоцентрами землетрясений: Чуйского (профиль И-И, т.н. 14 - 15), Урэг-Нурского (профиль Б-Б, т.н. 1 - 2 и профиль 33, т.н. 17 - 18) и Шагонарского (профиль $\Gamma-\Gamma$, т.н. 10) с $\boldsymbol{\phi}_{\mathbf{i n}}{ }^{170}=0.1-0.2 \%$; Тээлинского (профиль А-А, т.н. 7 - 8; профиль Г-Г, т.н. 3 - 4) и Каа-Хемского (профиль Ж-Ж, т.н. 11 -

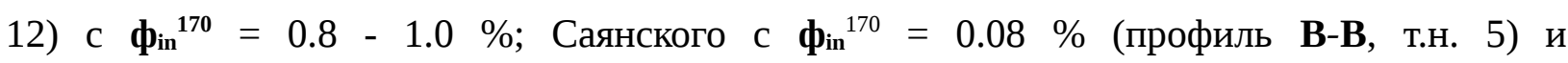
Самагалтайского с $\boldsymbol{\phi}_{\text {in }}{ }^{170}=0.5$ \% (профиль Б-Б, т.н. 20), а также обрамляющие их разломы. Например, глубинные разломы с северным простиранием: Восточно-Шапшальский $\left(\mathrm{H}_{\mathrm{in}}=\right.$ 10 - 20 км), Восточно-Кузбаский и Сарасинский $\left(\mathrm{H}_{\mathrm{m}}=1-40\right.$ км), МартайгинскоПатынский $\left(\mathrm{H}_{\mathrm{m}}=1-5\right.$ км) характеризуются значениями $\boldsymbol{\phi}_{\mathbf{m}}{ }^{170}=0.6-1.2 \%$; с северозападным простиранием: Шапшальский $\left(\mathrm{H}_{\text {in }}=1-4\right.$ км и $\mathrm{H}_{\text {in }}=20-25$ км$)-\boldsymbol{\phi}_{\text {in }}{ }^{170}=0.3-0.5$ $\%$, Восточно-Таннуольский, Унгешский и Балыктыг-Хемский $\left(\mathrm{H}_{\text {in }}=1-30\right.$ км$)-\boldsymbol{\phi}_{\text {in }}{ }^{170}=0.9$ $\%$, с северо-восточным простиранием (Убсунур-Баянкольский, $\mathrm{H}_{\text {in }}=1-4$ км) - фin $^{170}=0.8$ 1.0 \% и с субширотным простиранием (Агардакский) - $\boldsymbol{\phi}_{\text {in }}{ }^{170}=0.5 \%$.

Минимальное содержание флюида $\left(\boldsymbol{\phi}_{\text {in }}{ }^{170}<0.1 \%\right)$ свойственно глубинным разломам: Башеланскому, Южно-Теректинскому, Курайскому, Хемчикско- 
Куртушубинскому, Азасскому и Каа-Хемскому, вдоль которых ориентированы растягивающие девиаторные напряжения (рис. 5) [Ребецкий и др., 2013]. Низкое содержание флюида (до $\boldsymbol{\phi}_{\text {in }}{ }^{170}=0.07-0.15 \%$ ) в разломах Батеневского массива объясняется относительно спокойным режимом его развития. Для блоков массива, расположенных глубже 10 км, в его западной части $\boldsymbol{\phi}_{\text {in }}{ }^{170} \approx 0.1-0.2 \%$ (профиль I-I), а глубже 25 км $\boldsymbol{\phi}_{\text {in }}{ }^{170}=0.3$ \%. Это область, прилегающая к зоне с повышенным тепловым потоком, пониженной скоростью обменных волн и повышенным положением границы Мохо [Белявский, Гойдина, 2012] (рис. 1). В восточной части Батеневского массива фin не превышает 0.05 \% (профиль III-III).

Впадины региона и их обрамление. Блоки с повышенным содержанием флюида выделяются на глубинах 15 - 25 км под Тувинской котловиной, Кызылской, Убсунурской впадинами и их горным обрамлением. На глубинах 20 - 30 км проводящие блоки картируются под каледонидами эвгеосинклинального и миогеосинклинального типов: профиль Ж-Ж, т.н. 4 - 9 с 中in $^{170}=0.9$ \%, профиль В-В, т.н. 1 - 2 с $\boldsymbol{\phi}_{\text {in }}{ }^{170}=0.05-0.1 \%$, профиль А-А, т.н. 3 - 4, 5 - 8, 11 - 12 соответственно с $\boldsymbol{\phi}_{\text {in }}{ }^{170}=0.06,0.9$ и 0.05 \%; под байкалидами: эвгеосинклинального типа и орогенной стадии развития (профиль $\boldsymbol{\Gamma}$ - $\boldsymbol{\Gamma}$, т.н. 28 - 30 и 15 - 20) с $\boldsymbol{\phi}_{\text {in }}{ }^{170}=0.3-0.5$ \% и посторогенной активизации (профиль Д-Д, т.н. 8 11; профиль Г-Г, т.н. 26 - 27; профиль Б-Б, т.н. 19 - 20) с $\boldsymbol{\phi ~}_{\text {in }}{ }^{170}=0.5$ - 0.85 \%. Не выделены коровые проводящие блоки под Западно-Сангиленским срединным массивом и Кузнецкой молассоидной угленосной СФЗ.

\section{РЕЗУЛЬТАТЫ ИССЛЕДОВАНИЙ}

1. Содержание всего водного флюида в горной породе оценивалось по формуле Шенкленда - Ваффа при его минерализации солями $\mathrm{NaCl}$ с $\boldsymbol{C}=170$ г/л. В качестве реперных значений приняты УЭС флюида, полученные по данным лабораторных исследований, при адсорбции части ионов $\mathrm{Na}^{+}, \mathrm{Cl}^{-}$на стенках капилляров и их концентрации в карманах обводненной породы [Shimojuku et al., 2014] (табл. 2). В очаговых зонах землетрясений содержание флюида $\mathbf{\phi i n}^{170}$ достигает значений (0.4 - 1.0) $\boldsymbol{\phi}_{\mathrm{v}}$, оцененных по дефициту скорости продольных волн $\Delta \mathrm{V}_{\mathrm{p}}$. В близких пределах будет изменяться и точность оценок содержания флюида, при этом относительные изменения $\boldsymbol{\phi}_{\text {in }}$ в регионе сохраняются, если минерализация флюида в регионе не изменяется.

2. Основная часть гипоцентров землетрясений расположена (рис. 3 - 5) над кровлей проводников и вблизи глубинных низкоомных разломов с $\rho_{\text {in }}=10-200$ Ом'м $\left(\phi_{\text {in }}{ }^{170}=0.06\right.$ - 
1.0 \%). Они коррелируют с положением доменов, характеризующихся повышенным затуханием обменных волн землетрясений и пониженными скоростями продольных волн (данные MOB3-ГСЗ). Это свидетельствует о повышенной трещиноватости и обводненности блоков коры в очаговых зонах землетрясений. Максимальное содержание флюида $\left(\boldsymbol{\phi}_{\text {in }}{ }^{170}=0.5-0.9\right.$ \%) свойственно Тээлинскому, Самагалтайскому и Каа-Хемскому очагам землетрясений, расположенным в западной и восточной частях Тувинской котловины и Убсунурской впадине, а минимальное $\left(\boldsymbol{\phi}_{\text {in }}{ }^{170}=0.1-0.2 \%\right)-$ Алтайскому, Шапшальскому, Шагонарскому и Большепорошскому очагам.

3. Повышенной флюидонасыщенностью $\left(\boldsymbol{\phi}_{\text {in }}{ }^{170}=0.15-0.6 \%\right)$ характеризуются глубинные разломы, простирающиеся на: север (Восточно-Шапшальский, ВосточноКузбаский, Сарасинский, Мартайгинско-Патынский), северо-запад (Шапшальский, Восточно-Таннуольский, Унгешский, Балыктыг-Хемский) и северо-восток (УбсунурБаянкольский, Агардакский). На глубинах 1 - 5 км у Мартайгинско-Патынского, ВосточноКузбаского, Сарасинского, Восточно-Таннуольского, Унгешского, Балыктыг-Хемского и Убсунур-Баянкольского разломов содержание флюида достигает 0.9 - 1.2 \%. Минимальное содержание $\boldsymbol{\phi}_{\text {in }}{ }^{170}=0.08-0.1 \%$ свойственно разломам (рис. 5), вдоль которых ориентированы растягивающие девиаторные напряжения [Ребецкий и др., 2013].

4. Блоки с содержанием флюида до 0.3 - 0.8 \% выделяются на глубинах 15 - 25 км под каледонидами восточной и западной Тувы, Тувинской котловиной, Убсунурской и Кызылской впадинами. Ориентация растягивающих напряжений под ними изменяется при движении с востока на запад (рис. 5) [Ребецкий и др., 2013], а составляющие векторов растяжения, ориентированных ортогонально к простиранию впадин и разломов, способствуют поступлению глубинного флюида в верхнюю и среднюю части коры. Малыми значениями $\boldsymbol{\phi}_{\text {in }}{ }^{170}=0.1-0.15 \%$ характеризуются блоки коры под Чуйской и Курайской впадинами, вдоль которых ориентированы растягивающие напряжения (рис. 4, 5). Об их субширотном направлении в пределах Алтайского и Шапшальского очагов свидетельствуют и разрывные нарушения типа сбросов границы Мохо и её сокращение под очаговыми зонами с 55 до 50 км, образующие в коре антиклинальные структуры амплитудой до 5 км [Белявский, Ракитов, 2012].

5. Высокие значения ф⿰ и фіп под Кызылской впадиной и в переклинальных частях Тувинской котловины могут быть вызваны растяжением под ними блоков литосферы, лежащих на продолжении Байкальской рифтовой зоны [Курганьков, 2001; Кузнецова, 1997]. Это подтверждается томографической моделью (комплекс МОВЗ - ГСЗ), в которой 
домен с дефицитом скорости $\mathrm{V}_{\text {р }}$ до 2.5 \% [Золотов и др., 2006] расположен под впадиной на глубине более 100 км. Такой мантийный диапир может вызвать повышенное содержание водной фракции флюида [Файф и др., 1981] и в верхних блоках литосферы. Надо отметить, что блоки с содержанием флюида до ф $=1-1.6$ \% (при $\boldsymbol{\phi}_{\text {in }}=0.6-0.9$ \%) выделяются под Байкальской рифтовой зоной глубже 17 км, как и астеносферные проводящие выступы глубже 100 км [Ваньян, Шиловский, 1983] или аномально проводящая мантия [Геоэлектрическая модель...,, 1998]. Однако в Алтае-Саянском регионе на глубинах более 30 км температура достигает значений $600-800^{\circ} \mathrm{C}$ [Матросов, Шапошников, 1988], которых достаточно для образования надкритического водного флюида при дегидратации пород амфиболитовой фации метаморфизма. Дальнейшая миграция флюида вверх приводит к понижению УЭС в блоках, характеризующихся повышенной проницаемостью.

Авторы благодарны сотрудникам ФГУП КНИИГиМС и Всероссийского научноисследовательского института геофизических методов разведки, выполнявшим полевые наблюдения и обработку данных МТЗ и МОВЗ-ГСЗ по Алтае-Саянскому региону. 


\section{ЛИТЕРАТУРА}

Белявский В.B. Трехмерная интерпретация магнитотеллурических данных. LAPLAMBERT. Saarbrucken, Deutschland, Academic Publishing, 2017, 554 c.

Белявский В.В. Геоэлектрическая модель Алтае-Саянской складчатой области. LAP-LAMBERT. Saarbrucken, Deutschland, Academic Publishing, 2014. Часть I - 251 с., Часть II - 186 с.

Белявский В.В. Построение инвариантных кривых магнитотеллурического зондирования // Физика Земли, 2007, № 3, с. 51 - 58.

Белявский В.В. Геоэлектрическая модель очаговых зон землетрясений юга АлтаеСаянского региона (по магнитотеллурическим данным) // Геология и Геофизика, 2020, т. 61 (1), с. $99-118$.

Белявский В.В., Гойдина А.Г. Трехмерная геоэлектрическая модель металлогенических зон Кузнецко-Алатауской складчатой области // Физика Земли, 2012, № $11-12$, с. 97 - 117.

Белявский В.В., Лозовский И.Н. Трехмерная инверсия магнитотеллурических данных при изучении очаговых зон землетрясений Алтае-Саянского региона. Физика Земли, 2020, № 4, с. 83 - 101.

Белявский В.В., Ракитов В.А. Флюидонасыщенность очаговых зон землетрясений Алтае-Саянского региона // Разведка и охрана недр, 2012, № 3, с. 13 - 20.

Белявский В.В., Шейнкман А.С., Килипко В.В. Возможности геоэлектрики при решении задач региональной и рудной геофизики на примере Алтае-Саянского региона // Геофизические исследования, 2018, т. 19 (1), с. 77 - 94.

Бердичевский М.Н., Дмитриев В.И., Новиков Д.Б., Пастуцан В.В. Анализ и интерпретация магнитотеллурических данных. М., Диалог, МГУ, 1997, 167 с.

Браун Д., Массет А. Недоступная Земля. М., Мир, 1984, 262 с.

Буслов М.М., Джен Х., Травин А.В., Отгонбаатар Д., Куликова А.В., Чен Минг, Глори С., Семаков Н.Н., Рубанова Е.С., Абилдаева М.А., Войтишек Е.Э., Трофимова Д.А. Тектоника и геодинамика Горного Алтая и сопредельных структур Алтае-Саянской складчатой области // Геология и геофизика, 2013, т. 54 (10), с. 1600 - 1627.

Булин Н.К., Егоркин А.В. Региональный прогноз нефтегазоносности недр по глубинным сейсмическим критериям. М., Центр ГЕОН, 2000, 193 с.

Ваньян Л.Л. Электромагнитные зондирования. М., Научный мир, 1997, 219 с.

Ваньян Л.Л., Хайдман Р.Д. О природе электропроводности активизированной земной коры // Физика Земли, 1996, № 4, с. 5 - 11.

Ваньян Л.Л., Шиловский П.П. Глубинная электропроводность океанов и континентов. М., Наука, 1983, 85 с.

Варенцов И.М. Общий подход к решению обратных задач магнитотеллурики в кусочно-непрерывных средах // Физика Земли, 2002, № 11, с. 11 - 33.

Геоэлектрическая модель тектоносферы Евразийского складчатого пояса и сопредельных территорий. Азаров Н.Я., Белявский В.В., Бердичевский М.Н., Борисова В.П., Бурахович Т.К., Ваньян Л.Л., Варенцов И.М., Голубцова Н.С., Гордиенко В.В., Завгородняя О.В., Каримов К.М., Кашурников А.В., Кулик С.Н., Логвинов И.М., Таль- 
Вирский Б.Б., Трапезников Ю.А., Чарушин А.Г., Чернявский Г.А., Шпак И.П. // Под редакцией Белявского В. В. и Кулика С. Н. Киев, Знання, 1998, 264 с.

Золотов Е.Е., Кадурин И.Н., Ракитов В.А., Лопатин Ю.К., Треусов А.В. Телесейсмическая томография Алтае-Саянского региона по геотраверсу КВАРЦ // Геофизика XXI столетия: 2005. Сборник трудов седьмых геофизических чтений им. В.В. Федынского (3 -5 марта, Москва). М., Научный Мир, 2006, с. 71 - 76.

Еманов А.Ф, Еманов А.А., Лескова Е.В, Фатеев А.Г. Подкорытова В.Г. Афтершоковая область Тувинских землетрясений 27.12.2011 г. с $M=6,6$ и 26.12.2012 г. с $M=$ 6.8. «Землетрясения России в 2012 году». Обниск, ГС РАН, 2014, с. 94 - 98.

Еманов А.Ф., Лескова Е.В., Еманов А.А., Подкорытова В.Г., Шевкунова Е.В. Саянское землетрясение 10 февраля 2011 г. с $\mathrm{Kp}=13.9, \mathrm{ML}=6.4, \mathrm{I}_{0}=7$ и особенности сейсмического режима Западного Саяна // Землетрясения Северной Евразии, 2011. Обниск, 2017, с. 323 - 331.

Еманов А.А., Лескова Е.В. Структурные особенности афтершокового процесса Чуйского (Горный Алтай) землетрясения // Геология и геофизика, 2005, т. 46 (10), с. 1065 1072.

Каракин А.В., Курьянов Ю.А., Павленкова Н.И. Разломы, трещиноватые зоны и волноводы в верхних слоях земной оболочки. М., Государственный научный центр Российской Федерации - ВНИИгеосистем, 2003, 222 с.

Киссин И.Г. Флюиды в земной коре: геофизические и тектонические аспекты. М., Наука, 2009, 328 с.

Курганьков П.П. Геодинамическая обстановка сейсмоактивных районов АлтаеСаянской области и проблема внутриконтинентального рифтогенеза // Геология и минеральные ресурсы Центральной Сибири. Красноярск, КНИИГиМС, 2001, с. 31 - 44.

Кузнецова К.И. О факторе растяжения в процессе горообразования // Проблемы эволюции тектоносферы, М., ОИФЗ РАН, 1997, с. 388 - 403.

Лескова Е.В., Еманов А.А. Иерархические свойства поля тектонических напряжений в очаговой области Чуйского землетрясения 2003 года // Геология и геофизика, 2013, т. 54 (1), с. 113 - 123.

Лескова Е.В. (отв. сост.) Каталог механизмов очагов землетрясений АлтаеСаянского региона за 2008 г. $(N=1)$. Землетрясения Северной Евразии, 2008 год. Обнинск: ГС PAH, 2014. 520 c.

Лисейкин А.В., Соловьев В.М. Сейсмотомографическая модель очаговой зоны Чуйского землетрясения (Горный Алтай) // Геология и геофизика, 2005, т. 46 (10), с. 1073 1082.

Матросов П.С., Шапошников Г.Н. Алтае-Саянский регион и ЗабайкальскоВерхнеамурский регионы. Геологическое строение СССР и закономерности размещения полезных ископаемых. Т. 7. Сборник научных трудов. Л., Недра, 1988, 299 с.

Моисеенко У.И, Смыслов А.А. Температура земных недр. Л., 1986, 180 с.

Монгуш С.-С.С. Уточнение исходной сейсмичности по мониторингу республики Тыва. Материалы Всероссийской научно-практической конференции (17-18 ноября 2015 г., Кызыл, Россия) «Сейсмическая безопасность региона и воздействие сейсмологических и социально-экономических факторов на его развитие». Кызыл, РИО ТувГУ, 2015, с. 38 44. 
Петкевич Г.И., Вербицкий Т.З. Исследование упругих свойств пористых геологических сред, содержащих жидкости. Киев, Наукова Думка, 1965, 75 с.

Райс Дж. Механика очага землетрясений. М., Мир, 1982, 217 с.

Ребецкий Ю.Л., Кучай О.А., Маринин А.В. Напряженное состояние и деформации земной коры Алтае-Саянской складчатой области // Геология и геофизика, 2013, т. 54 (2), с. $271-291$.

Файф У., Прайс И., Томпсон Ф. Флюиды в земной коре. М., Мир, 1981, 433 с.

Физические свойства горных пород и полезных ископаемых (петрофизика) Справочник геофизика. Под ред. Дортмана Н.В. М., Недра, 1984, 455 с.

Archie G.E. Introduction to Petrophysies of Reservoir Rocks // Bull. of Americ. Ass. of Petr. Geol., 1950, v. 34 (5), p. 943-961.

Avdeeva A., Moorkamp M., Avdeev D., Jegen M., Miensopust M. Three-dimensional inversion of magnetotelluric impedance tensor data and full distortion matrix // Geophysical Journal International, 2015, v. 202(1), p. 464 - 481. doi: 10.1093/gji/ggv144

Counil J.L., le Mouel J.L, Menvielle M. Associate and conjugate directions concepts in magnetotellurics // Annales Geophysicae, 1986, v. 4(2), p. 115 - 130.

Druskin V., Knizhnerman L. Spectral approach to solving three-dimensional Maxwell's diffusion equations in the time and frequency domains // Radio Science, 1994. v. 29 (4), p. 937953.

Siripunvaraporn W., Egbert G., Lenbury Y, Uyeshima M. Three-dimensional magnetotelluric inversion: data-space method // Physics of the Earth and Planetary Interiors, 2005, v. 150(1-3), p. 3 - 14. doi: 10.1016/j.pepi. 2004.08.023.

Shimojuku A., Yoshino T., Yamazaki D. Electrical conductivity of brine-bearing quartzite at $1 \mathrm{GPa}$ : implications for fluid content and salinity of the crust // Earth Planet Sp., 2014, 66, 2. doi: 10.1186/1880-5981-66-2.

Shankland T.I., Waff H.S. Partial melting and electrical conductivity anomalies in the upper mantle // J. Geophys. Res., 1977, v. 82 (33), p. 5409 - 5417.

Wyllie M.R.J., Gregory A.R. Gardner L.W. Elastic wave velocities in heterogeneous and porous media // Geophysics, 1956, v. 21, p. 41 - 70. 


\section{Список условных обозначений:}

$M_{h y}, \mathrm{H}_{\mathrm{hy}}$ - магнитуды и глубины главных событий;

$M_{\mathrm{af}}, \mathrm{H}_{\mathrm{af}}-$ магнитуды и глубины афтершоков;

$\left|\mathrm{Z}_{\mathrm{xy}}\right|,\left|\mathrm{Z}_{\mathrm{yx}}\right|$ - модули главных значений тензора импеданса;

$\left[\mathrm{Z}_{\mathrm{ob}}\right], \mathrm{Z}_{\text {ob }}^{\mathrm{maxH}} \mathrm{Z}_{\text {ob }}^{\mathrm{minH}}$ - матрица экспериментальных импедансов и её инвариантные значения;

$\left|\mathrm{Z}_{\operatorname{maxн}}\left(\Theta_{\text {mахн }}\right)\right|-$ максимальные и $\left|\mathrm{Z}_{\min }\left(\Theta_{\min H}\right)\right|-$ минимальные значения модулей импедансов индукции;

$\mathrm{Z}_{\text {obaxHN }}^{\mathrm{minHN}} \mathrm{Z}_{\text {ob }}^{\mathrm{m}}$ - нормализованные экспериментальные импедансы индукции;

$\rho_{m}^{\operatorname{maxH}}, \rho_{m}^{\min H} \rho_{o b}^{\text {max HN }}, \rho_{o b}^{\min H N}-$ модельные кривые кажущегося удельного электрического сопротивления и средние нормализованные экспериментальные кривые МТЗ (для каждого из периодов наблюдений);

$\mathrm{Z}_{\mathrm{maxH}}, \mathrm{Z}^{\mathrm{minH}}{ }_{\mathrm{m}}$ - модельные максимальные и минимальные значения импедансов индукции;

$\check{Z}_{\text {maxH }}^{\text {ob}, ~} \check{Z}_{\text {ob }}^{\operatorname{minH}}$ - средние значения в группах экспериментальных максимальных и минимальных импедансов индукции (для каждого из периодов наблюдений);

$\delta_{\text {in }}^{\text {pxy }}, \delta^{\text {pyx }}{ }_{\text {in }}-$ погрешности трехмерной инверсии;

$\rho^{\mathrm{m}}\left(\mathrm{H}_{\mathrm{m}}\right), \rho^{\mathrm{in}}\left(\mathrm{H}^{\mathrm{in}}\right)$ - распределения удельного электрического сопротивления с глубиной: модельные и полученные при 3D инверсии;

т.и. - точки инверсии, заданные на сетке дискретизации;

т.н. - точки наблюдения экспериментальных кривых МТЗ;

$\boldsymbol{\phi}_{\boldsymbol{p}}$ - содержание флюида (в \%), определенное по УЭС;

$\boldsymbol{\phi}_{\text {in }}$ - содержание флюида (в \%), определенное по УЭС (3D инверсия);

$\boldsymbol{\phi}_{\mathbf{v}}$ - содержание флюида (в \%), определенное по скорости продольных волн. 


\section{Данные об авторах}

Белявский В.В. Доктор технических наук, доцент, ведущий научный сотрудник ЦГЭМИ ИФЗ РАН, г. Москва, г. Троицк.

Домашний адрес. г. Москва, ул. Народного ополчения, дом 7, кор. 3., кв. 198, тел.: 89032467217, 84991977102, e-mal: victor.belyavsky@list.ru.

Подпись Белявского В.В.

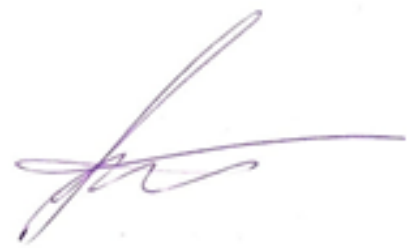

Лозовский И.Н., н.с., ЦГЭМИ ИФЗ РАН, г. Москва, г. Троицк.

Подпись Лозовского И.Н.

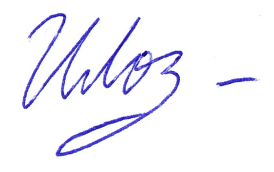




\section{ПОДРИСУНОЧНЫЕ ПОДПИСИ}

Рис. 1. Профили МТЗ на схеме структурно-геологического районирования АлтаеСаянского региона [Матросов, Шапошников, 1988]. Условные обозначения: 1 раннепротерозойские выступы - Западно-Сангиленский (3-С) и Томско-Терсинский (Т-Т); 2 - СФЗ байкалид - выступы (а) и чехлы устойчивых массивов (б); 3 - каледониды эвгеосинклинальные с ассоциациями: а - офиолитовыми, б - базальто-андезитовыми, в базальт-риолитовыми, г - миогеосинклинального типа - Хемчикская (Хм), АнуйскоЧуйская (А-Ч); 4 - СФЗ орогенной стадии: а - вулканогенно-молассоидные - Тувинская (Ту), б - молассоидные угленосные - Кузнецкая (Ку); 5 - СФЗ моласс: а - кайнозойских Чуйская (Чу), Убсунурская (Уб); б - юрских - Кызылская (Кз); впадины: СевероМинусинская (CM), Южно-Минусинская (ЮМ). Массивы: Батеневский (БM), Мрасский $(M M) ; 6$ - Бийско-Барнаульский массив; 7 - основные глубинные разломы: 1 - СардиноСорский, 2 - Батеневский, 3 -Саяно-Батеневский, 4 - Восточно-Кузбасский, 5 - МартайгинскоПатынский, 6 - Саяно-Минусинский, 7 - Хемчикско-Куртушубинский, 8 - Азасский, 9 Уюкский, 10 - Башеланский, 11 - Сарасинский, 12 - Южно-Теректинский, 13 Шапшальский, 14 - Шуйский, 15 - Убсунур-Баянкольский, 16 - Восточно-Таннуольский, 17 - Байсютский, 18 - Каа-Хемкский, 19 - РС, 20 - Курайский, 21 - Центрально-Чуйский, 22 - Карасуг-Улатайский, 23 - Кантегинский, 24 - Восточно-Шапшальский, 25 - ЮжноТаннуольский, 26 - Барлыкский; 27 - Балыктыг-Хемский, 28 - Унгешский, 29 Агардакский; 8 - профили МТЗ: А-А, Б-Б, В-В, Г-Г, Д-Д, Е-Е, Ж-Ж, 3-3, И-И, I, II, III, IV (в квадратах) и номера т.н; 9 - эпицентральные поля очаговых зон землетрясений: 1 Алтайского, $\underline{2}$ - Шапшальского, $\underline{3}-$ Тээлинского, $\underline{4}-$ Каа-Хемского, $\underline{5}$ Большепорошского, $\underline{6}$ - Шагонарского, $\underline{7}$ - Самагалтайского; звезды - эпицентры главных событий; 10 - проекция контура низкоскоростного коромантийного тела с повышенным тепловым потоком. Прямоугольниками выделены площади исследований - Кузнецкий Алатау (на севере), Западные Саяны и Тува (в центральной части) и Горный Алтай (на юге). Внизу - фрагмент карты сейсмического районирования ОСР-2014 и интенсивность сейсмических сотрясений в баллах.

Рис. 2. Карты удельного электрического сопротивления, построенные по результатам трехмерной интерпретации МТ данных для глубин: 10, 20 и 30 км. Сверху показано положение: эпицентральных полей очаговых зон землетрясений (красные эллипсы), эпицентров главных событий (звезды), глубинных разломов (жирные сплошные и пунктирные линии), границ СФЗ, профилей МТЗ и т.н. (см. рис. 1). Справа - шкала $\lg (\rho)$, Ом·м. 
Рис. 3. Результаты 3D-инверсии инвариантных значений импедансов $\check{Z ̆}^{\operatorname{maxH}}{ }_{\text {ob }}$, ${ }^{\operatorname{minH}}{ }_{\text {ob }}$ вдоль профилей МТЗ А-А и Г-Г. Малые звезды - гипоцентры землетрясений с $M=1.5$ 3.3 (зарегистрированные за время метода МOB3); большие звезды - гипоцентры землетрясений: Тээлинского (03.06.2008, профиль Г-Г), Шагонарского (30.04.2013, профиль Г-Г) и Алтайского (Чуйского, 2003, профиль А-А). Эллипсы границы зон повышенного затухания обменных волн с К > 0.0009 дБ/км (сплошная линия) и волноводов на геотраверсе «Кварц» (линия со штриховкой). Сверху даны номера групп т.и. МТ3, названия структурных единиц и глубинных разломов. Справа приведена шкала УЭС $\lg (\rho)$, $\mathrm{OM} \cdot \mathrm{M}$.

Рис. 4. Содержание жидкого флюида в низкоомных блоках земной коры, выделенных на глубинах более 5 км. Изолинии - значения $\boldsymbol{\phi}^{170}$ (в процентах).

Рис. 5. Расположение блоков с повышенным содержанием флюида $\mathbf{\phi}^{\mathbf{1 7 0}}$ на глубинах свыше 5 км (на схеме тектонического районирования). Стрелками показаны направления растягивающих девиаторных напряжений [Ребецкий и др., 2013]. 
Таб1л. 1. Очаговые зоны землетрясений.

\begin{tabular}{|c|c|c|c|}
\hline $\begin{array}{l}\text { Очаговые зоны } \\
\text { землетрясений }\end{array}$ & $\begin{array}{l}\text { Главные события, время, магнитуды, } \\
\text { глубины }-M_{h y}, \mathrm{H}_{\mathrm{hy}}(\text { км); магнитуды и глубины } \\
\text { афтершоков }-M_{\mathrm{af}}, \mathrm{H}_{\mathrm{af}}(\mathrm{kм})\end{array}$ & $\begin{array}{l}\text { Размеры эпицентрального поля (км) и } \\
\text { его расположение }\end{array}$ & $\begin{array}{l}\text { Ориентация, } \quad \text { амплитуды, } \\
\text { перемещения блоков в год }\end{array}$ \\
\hline Алтайская & $\begin{array}{l}\text { Чуйское, } 27.09 .2003 \text {, } \\
M_{h y}=7.3, \mathrm{H}_{\mathrm{hy}}=8.8 ; M_{\mathrm{af}}=1-5.3,2<\mathrm{H}_{\mathrm{af}}<25\end{array}$ & $\begin{array}{l}\text { 150×100, пересечение Курайского, } \\
\text { Башеланского, Центрально-Чуйского } \\
\text { разломов }\end{array}$ & $\begin{array}{l}\text { вдоль разломов на северо- } \\
\text { западном борту Чуйской и } \\
\text { Курайской впадин, до } 2 \text { мм }\end{array}$ \\
\hline Шапшальская & $\begin{array}{l}\text { Урэг-Нурское, } 15.05 .1970, \\
M_{h y}=7.0, \mathrm{H}_{\mathrm{hy}}=12 ; M_{\mathrm{af}}=1-5,3<\mathrm{H}_{\mathrm{af}}<23\end{array}$ & $\begin{array}{l}120 \times 45, \text { северо-запад } \text { Убсунурской } \\
\text { впадины }\end{array}$ & $\begin{array}{l}\text { по Шапшальскому разлому, до } \\
2 \text { мм }\end{array}$ \\
\hline Тээлинская & $\begin{array}{l}\text { Тээлинское, 03.06.2008, } \\
M_{h y}=4.2, \mathrm{H}_{\mathrm{hy}}=14 ; M_{\mathrm{af}}=1-4,4<\mathrm{H}_{\mathrm{af}}<20\end{array}$ & $\begin{array}{l}\text { 130×70, стык по Барлыкскому разлому, } \\
\text { вдоль разновозрастных Хемчикских } \\
\text { СФЗ }\end{array}$ & $\begin{array}{l}\text { вдоль } \\
\text { Куртушибинского разлома, до } \\
2 \text { мм }\end{array}$ \\
\hline Шагонарская & $\begin{array}{l}\text { Шагонарское, 30.04.2013, } \\
M_{h y}=5.6, \mathrm{H}_{\mathrm{hy}}=10 ; M_{\mathrm{af}}=2-5,8<\mathrm{H}_{\mathrm{af}}<25\end{array}$ & $\begin{array}{l}\text { 100×50, Тувинская и Кызылская } \\
\text { впадины }\end{array}$ & $\begin{array}{l}\text { вдоль границы Хемчикской и } \\
\text { Тувинской СФЗ, до } 2 \text { мм }\end{array}$ \\
\hline Каа-Хемская & $\begin{array}{l}\text { Тувинские: 27.12.2011, 26-28.02.2012, } M_{h y}= \\
6.5-6.8, \mathrm{H}_{\mathrm{hy}}=6.5-17 ; M_{\mathrm{af}}=1-5,2<\mathrm{H}_{\mathrm{af}}<30\end{array}$ & $\begin{array}{l}60 \times 40 \text {, пересечение Байсютского и Каа- } \\
\text { Хемского разломов }\end{array}$ & $\begin{array}{l}\text { вытянуто вдоль Каа-Хемского } \\
\text { разлома, до } 1 \text { мм }\end{array}$ \\
\hline Большепорожская & $\begin{array}{l}\text { Саянское, 10.02.2011, } \\
M_{h y}=6.4, \mathrm{H}_{\mathrm{hv}}=10 ; M_{\mathrm{af}}=2-3,6<\mathrm{H}_{\mathrm{af}}<25\end{array}$ & $\begin{array}{l}\text { 30×10, Западно-Саянская СФ3, север } \\
\text { Кантегирского разлома }\end{array}$ & $\begin{array}{l}\text { ортогонально к Усинскому } \\
\text { разлому, } 1.2 \text { мм }\end{array}$ \\
\hline
\end{tabular}


Табл. 2. Зависимость УЭС водного флюида от глубины, температуры, давления и минерализации.

\begin{tabular}{|c|c|c|c|c|c|c|c|}
\hline Давление, кбар & 0.001 & 1.0 & 2.7 & 4.5 & 5.3 & 9.7 & 14.2 \\
\hline Глубина, км & 0.0 & 5.0 & 10.0 & 15.0 & 20.0 & 35.0 & 50.0 \\
\hline$T=100^{\circ}$ & 0.17 & & & & & & \\
\hline $\boldsymbol{C}=10$ г/л & 0.05 & 0.18 & 0.17 & 0.16 & 0.15 & 0.15 & 0.14 \\
\hline$C=50$ г/л & רחם & 0.051 & 0.05 & 0.044 & 0.043 & 0.04 & 0.04 \\
\hline$C=170$ г/л & & 0.02 & 0.02 & 0.018 & 0.017 & 0.016 & 0.016 \\
\hline$T=200^{\circ}$ & & & & & & & \\
\hline $\boldsymbol{C}=10$ г/л & 0.10 & 0.14 & 0.12 & 0.11 & 0.10 & 0.095 & 0.9 \\
\hline $\boldsymbol{C}=50$ г/л & 0.03 & 0.043 & 0.035 & 0.031 & 0.027 & 0.025 & 0.023 \\
\hline$C=170$ г/л & 0.12 & 0.016 & 0.014 & 0.012 & 0.011 & 0.01 & 0.01 \\
\hline$C=170$ г/л & & 0.15 & 0.13 & 0.1 & $\mathbf{0 . 0 8 7}$ & & \\
\hline$T=400^{\circ}$ & & & & & & & \\
\hline $\boldsymbol{C}=10$ г/л & 0.055 & 0.13 & 0.08 & 0.07 & 0.065 & 0.06 & 0.056 \\
\hline $\boldsymbol{C}=50$ г/л & 0.015 & 0.037 & 0.026 & 0.02 & 0.018 & 0.017 & 0.015 \\
\hline $\boldsymbol{C}=170$ г/л & & 0.013 & 0.011 & 0.009 & 0.007 & 0.007 & 0.006 \\
\hline$C=170$ г/л & & 0.13 & 0.1 & 0.07 & 0.065 & 0.06 & \\
\hline$T=600^{\circ}$ & & & & & & & \\
\hline $\boldsymbol{C}=10$ г/л & & 0.15 & 0.08 & 0.07 & 0.065 & 0.06 & 0.055 \\
\hline $\boldsymbol{C}=50$ г/л & & 0.041 & 0.024 & 0.015 & 0.015 & 0.013 & 0.011 \\
\hline $\boldsymbol{C}=170$ г/л & & & 0.01 & 0.006 & 0.006 & 0.0053 & 0.0045 \\
\hline$C=170$ г/л & & & 0.1 & 0.07 & $\mathbf{0 . 0 7}$ & 0.05 & \\
\hline$T=800^{\circ}$ & & & & & & & \\
\hline $\boldsymbol{C}=10$ г/л & & & 0.08 & 0.06 & 0.055 & 0.045 & 0.04 \\
\hline $\boldsymbol{C}=50$ г/л & & & 0.023 & 0.015 & 0.015 & 0.011 & 0.001 \\
\hline $\boldsymbol{C}=170$ г/л & & & 0.01 & 0.006 & 0.006 & 0.005 & 0.004 \\
\hline$C=170$ г/л & & & 0.10 & 0.07 & 0.065 & 0.05 & 0.04 \\
\hline
\end{tabular}




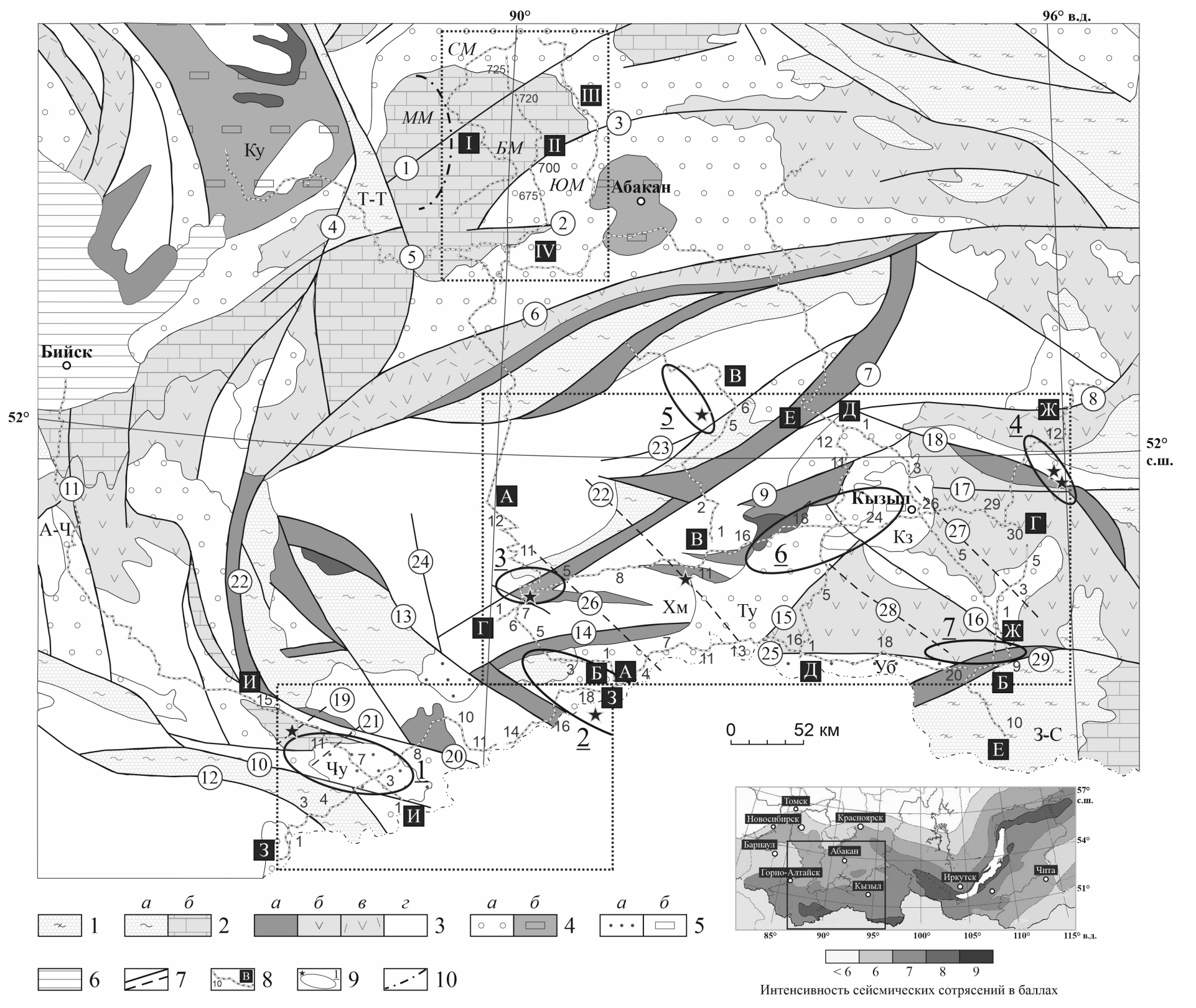




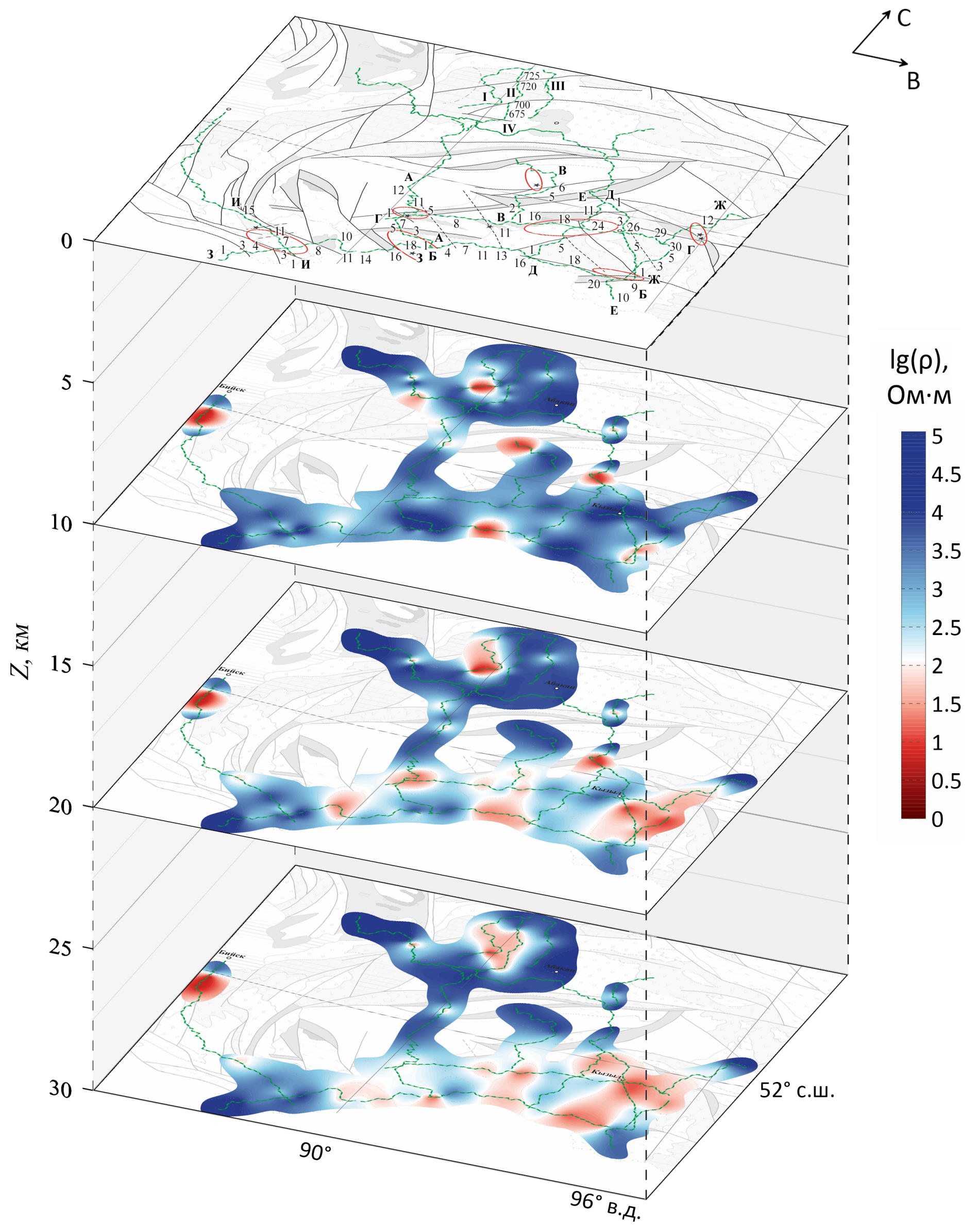



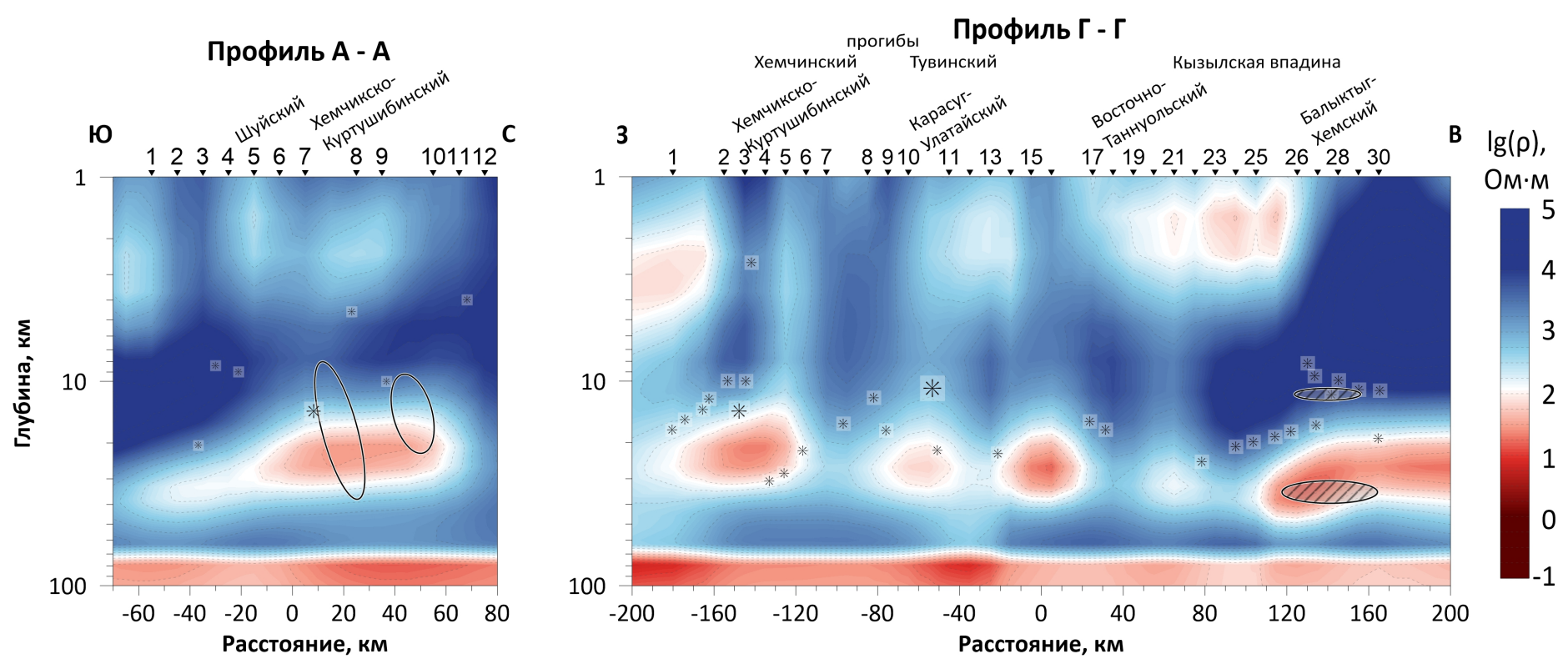


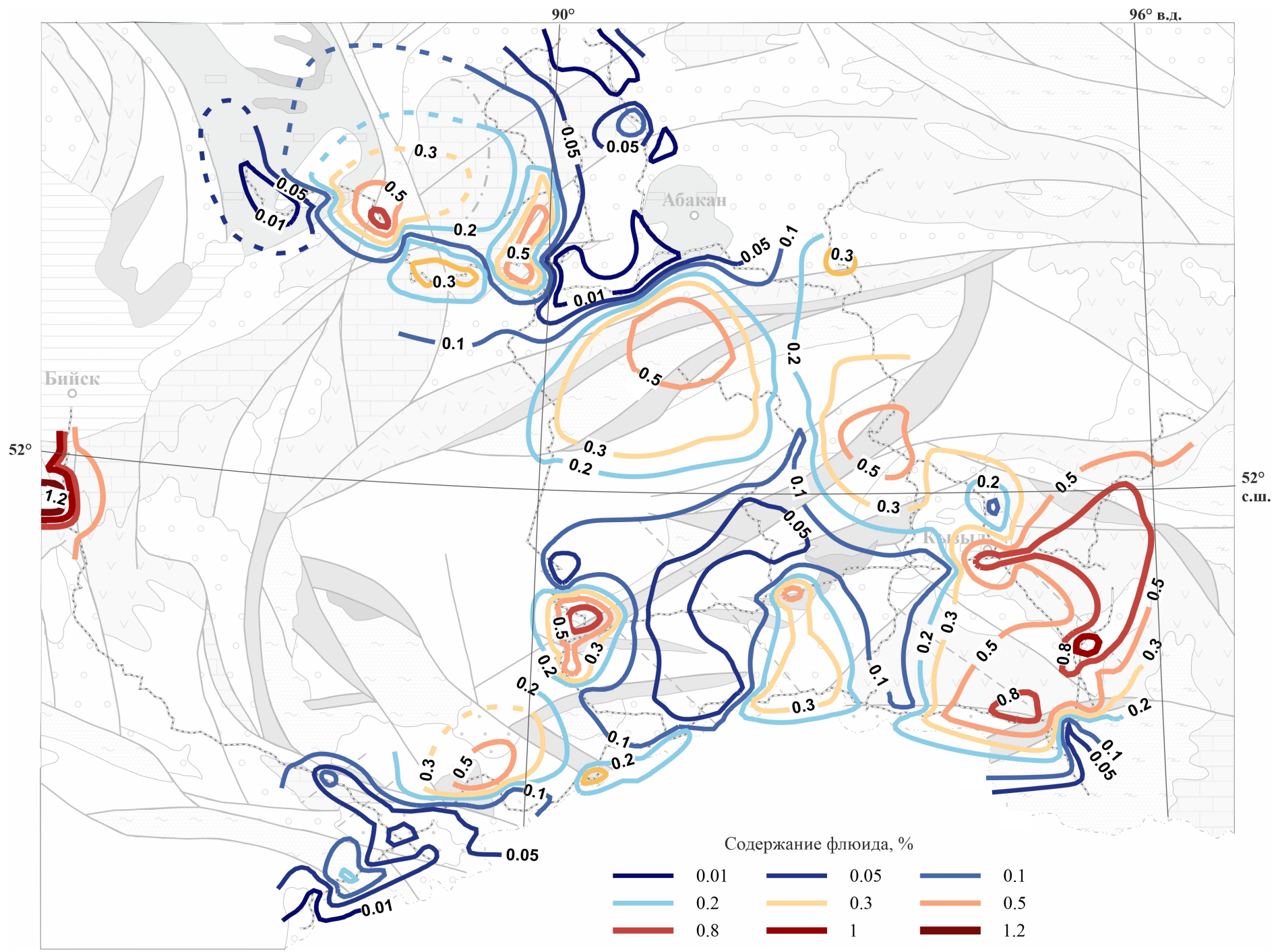




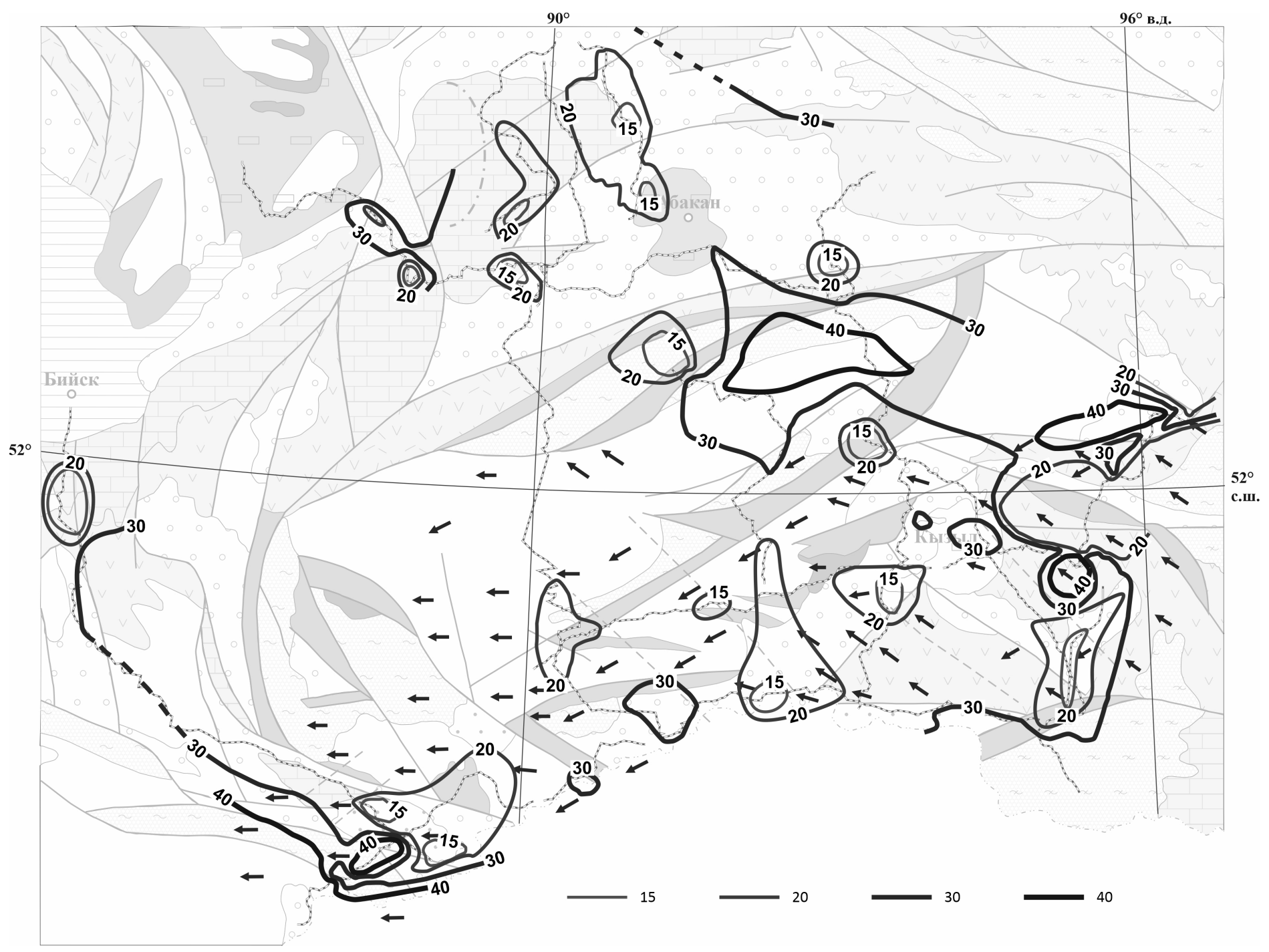

